\title{
APPARENT USE OF A ROCK CREVICE AS A NOCTURNAL ROOST BY A RUBY-CROWNED KINGLET
}

\author{
EMILIE STRAUSS, P.O. Box 9426, Berkeley, California 94709; \\ desertpeach@earthlink.net \\ DAVID L. SWANSON, Department of Biology, University of South Dakota, \\ Vermillion, South Dakota 57069; david.swanson@usd.edu
}

Relatively little is known about the locations of North American landbirds' winter roosts (Skutch 1989, Dobbs and Martin 2000). North American Piciformes and cavity-nesting passerines have frequently been documented using cavities and variations thereof for overnight roosts during the non-nesting season, but relatively little is known about where passerines that nest in cups or other open structures spend the night (Skutch 1989, Dobbs and Martin 2000, Antczak 2010). The Rubycrowned Kinglet (Regulus calendula), an insectivorous cup-nesting species, has not been observed either nesting or roosting in cavities (Swanson et al. 2008). It breeds in coniferous forests in Canada, Alaska, northern New England, and the western United States, and winters across western, mid-central, and southern North America south through Mexico to Guatemala. In central California, the Ruby-crowned Kinglet winters commonly (Lepthien and Bock 1976, Swanson et al. 2008).

On 17 November 2017, along Deer Flat Road about $1 \mathrm{~km}$ northwest of Juniper Campground, Mount Diablo State Park, Contra Costa County, California, Strauss observed and filmed a Ruby-crowned Kinglet evidently examining a rock crevice for use as a nocturnal roost. This occurred during a period of prolonged subnormal temperatures and the day after a powerful two-day Pacific storm came through central California. On a cold and windy day, Strauss was hiking with a friend in Mount Diablo State Park just after sunset. She was surprised to observe a kinglet flutter along the $2-\mathrm{m}$ rock face and plunge into a small opening in the rock. As the rock crevice was at eye level, $1.4 \mathrm{~m}$ above the height of the fire road, she immediately recorded this behavior with an iPhone SE5. The video, available at https://flickr.com/photos/76353343@ N05/31763450227/in/datetaken-public/, shows 1.08 minutes of activity. In the cavity, the kinglet rotated back and forth on its belly as though hollowing out a depression, then ceased movement while simultaneously sealing the entrance with fluffed vent and belly feathers. The crevice, which measured $2.8 \mathrm{~cm} \times 3.6 \mathrm{~cm}$ at the mouth and narrowed slightly after the opening, almost completely concealed the bird. On a subsequent visit, Strauss inserted a metal tape into the crevice, measuring a depth of 8.6 $\mathrm{cm}$. Most of the crevice was too narrow to be used by the bird. Using packing peanuts loosely inserted into the crevice, Strauss determined that the volume of the crevice available to the kinglet was approximately $31.2 \mathrm{~cm}^{3}$. After 65 seconds, she inadvertently flushed the bird when she repositioned the phone closer to the rock cavity. The bird flew approximately $30 \mathrm{~m}$ along the escarpment, perching briefly several times on the rock bank, and then returned within $4 \mathrm{~m}$ of the crevice. Strauss hastily departed the area as she did not want to further hinder its efforts to find shelter. At 17:20, when the bird entered the crevice, it was almost dark. Sunset was at 16:57 and civil twilight at 17:25. Upon exiting, the kinglet partially exposed a red crown patch, identifying it as a male. Ruby-crowned Kinglets have not been documented using cavities as foraging habitat, and the bird did not appear to peck or otherwise behave as if foraging.

The elevation of Juniper Campground is $896 \mathrm{~m}$. During the 24 hours prior to this observation, the closest weather station (Mount Diablo summit, $1173 \mathrm{~m}$, Station SJS02) recorded temperatures from 2.2 to $7.3^{\circ} \mathrm{C}$ and wind speeds from 14 to $63 \mathrm{~km} /$ $\mathrm{hr}$ with gusts to $73 \mathrm{~km} / \mathrm{hr}$. Juniper Campground is located approximately $2 \mathrm{~km}$ west- 
southwest and $275 \mathrm{~m}$ below Mount Diablo's summit. At 17:20, the approximate time when the bird entered the crevice, the summit temperature was $3.6^{\circ} \mathrm{C}$ and the wind was from the north at $55 \mathrm{~km} / \mathrm{hr}$, thus producing a wind chill of $-3.5^{\circ} \mathrm{C}$. The cliff and crevice face southwest and were thus slightly protected from wind. Weather data are from https://www.mdia.org/mount-diablo-summit-weather.

Kendeigh (1972) stated that in birds and mammals the rate of metabolism per unit weight increases as body weight declines. At 5.0-9.7 g (male weight), the Rubycrowned Kinglet is not only one of North America's smallest songbirds but also one of the smallest birds to winter regularly north of $38^{\circ} \mathrm{N}$ latitude (Kendeigh 1972, Blem and Pagels 1984, Swanson et al. 2008). How does such a small species survive cold winter nights? Observations of roosting in the Ruby-crowned Kinglet are limited; on several occasions solitary birds perched in tree limbs close to the trunk (Swanson et al. 2008), and twice over a period of two weeks one individual entered a Verdin (Auriparus flaviceps) nest at twilight (Farley 1993). Although the Ruby-crowned Kinglet is considered a "winter durable" species, Laurenzi et al. (1982) found that its numbers declined precipitously during a very dry, cold winter in the lower Colorado River valley, suggesting the birds had either died or migrated.

None of the members of the Regulidae nest in cavities (Martens and Päckert 2006). Winter roosting strategies of two other species, the Golden-crowned Kinglet (Regulus satrapa) and Goldcrest (R. regulus), include huddling in communal groups (Reinertsen et al. 1988, Heinrich 2003) and occasional roosting in enclosed spaces. Examples of roosting in enclosed spaces are limited to a few observations of Goldencrowned Kinglets entering squirrel nests at dusk (Blem and Pagels 1984) and a single observation of three Goldcrests entering a snow hollow in Finland at sunset (Lagerstrøm 1979:171). The snow hollow "consisted of a recess in an earth bank, which was partly covered by overhanging grass and snow, and by the mantle of snow on the lower edge of the recess"; the hollow measured $20 \mathrm{~cm}$ in breadth and $10 \mathrm{~cm}$ in depth and was situated $1.5 \mathrm{~m}$ above the level of an adjacent road. Blem and Pagels (1984) calculated that the Golden-crowned Kinglet's lipid reserves are inadequate for it to survive cold winter nights, so they suggested it likely enters hypothermia. But later studies (Reinertsen et al. 1988) found that Goldcrests receiving adequate nutrition did not become hypothermic because of group huddling at night. Ruby-crowned Kinglets are not known to enter hypothermia or to huddle in groups at night during cold weather (Swanson et al. 2008, Farley 1993).

Another adaptation to cold in the Regulidae is the "fluffiness factor." Both the Golden-crowned and Ruby-crowned kinglets are relatively well insulated because their contour plumage is denser (representing $8.9-11.1 \%$ of body weight) than found in 73 other passerine species. Generally, contour plumage averages $7.5 \%$ of body weight (Wetmore 1936). In spite of its high insulative capacity, the Ruby-crowned Kinglet's capacity for metabolic heat production appears lower than predicted for a bird of its size. Its summit metabolic rate (i.e., maximum cold-induced metabolic rate) is lower than predicted for its body mass. In fall, the metabolic rates of females and males (Swanson 2007) are only $82 \%$ and $91 \%$, respectively, of the allometric predictions for birds (Swanson and Garland 2009). Therefore, because of its lower than predicted metabolic capacity, the Ruby-crowned Kinglet's tolerance for cold might be relatively poor, which might also make finding an appropriate microclimate for winter roosting a priority.

Choosing enclosed or protected winter nocturnal roost sites provides many benefits for small birds, and these advantages have been fairly well studied. Roosting in a rocky substrate provides protection from both predators and parasites (Velky et al. 2010, Doucette et al. 2011). Birds roosting in cavities or domed nests reduce their nocturnal energy consumption by up to $43 \%$ in comparison to birds roosting in exposed sites (Walsberg 1985). Cooper (1999) found that Juniper Titmice (Baeolophus ridgwayi) and Mountain Chickadees (Poecile gambeli) roosting in boxes during 
winter in Utah saved 25.1-37.6\% on their nocturnal energy expense because of the increased air temperature and shelter from the wind the box affords. Mayer et al. (1982) reported that Carolina Chickadees (P. carolinensis) roosting in cavities in winter reduced their radiant heat loss by $60-100 \%$ and their convective heat loss by $100 \%$.

What energy savings would a Ruby-crowned Kinglet accrue by roosting in a rock crevice? No data on the basal metabolic rate (BMR) or metabolic-rate increments below the lower critical temperature are available for the Ruby-crowned Kinglet (Swanson et al. 2008), but a rough estimate of energy savings can be predicted from allometric equations for birds. From McKechnie and Swanson (2010), the BMR for a bird of $6.5 \mathrm{~g}$ (the average mass of a male Ruby-crowned Kinglet from Dunning 2008) should be $0.40 \mathrm{ml} \mathrm{O}_{2}$ per minute. The lower critical temperature (LCT) defining the lower boundary of the thermal neutral zone (assuming a nocturnal body temperature of $39^{\circ} \mathrm{C}$ ) should be $22.7^{\circ} \mathrm{C}$ for a 6.5 -g bird (Weathers and van Riper 1982). On the basis of the allometrically predicted minimum thermal conductance below the LCT, oxygen consumption should increase by $0.029 \mathrm{ml} \mathrm{O}_{2}$ per minute per degree Celsius for a 6.5-g bird (Schleucher and Withers 2001). Given these values, the predicted metabolic rate of a bird resting at night at various ambient temperatures $\left(T_{\mathrm{a}}\right)$ can be calculated as BMR $+\left(\left[\mathrm{LCT}-T_{\mathrm{a}}\right] \times 0.029\right)$. By this method, the metabolic rate of a 6.5-g bird resting at night at $3.6^{\circ} \mathrm{C}$ (the temperature measured at the Mount Diablo summit weather station) should be $0.954 \mathrm{ml} \mathrm{O}_{2}$ per minute. With the wind-chill value of $-3.5^{\circ} \mathrm{C}$ calculated from the wind speed measured at Mount Diablo, the bird's predicted metabolic rate should be $1.160 \mathrm{ml} \mathrm{O}_{2}$ per minute. Provided that wind chill in the crevice is negligible, the metabolic rate should be equivalent to that at the ambient temperature of $3.6^{\circ} \mathrm{C}$, which is a $17.8 \%$ reduction in energy expenditure relative to roosting in the open with full exposure to the wind. If the bird warms the temperature within the cavity, which seems likely given the cavity's small volume and the kinglet's high rate of metabolic heat production, the energy savings should be even greater.

There are few studies of the microhabitats of wild birds that roost in vegetation and do not huddle (Dobbs and Martin 2000, Antzac 2010). Walsberg (1986) found that the Phainopepla (P. nitens) selects mistletoe clumps (Phoradendron californicum) to minimize thermal loss to the wind. Similarly, Buttemer (1985) reported that the American Goldfinch (Spinus tristis) chooses roost sites on the basis of wind protection. Dobbs and Martin (2000) observed that American Robins (Turdus migratorius) often roost in dense vegetation but away from the most thermally protected microhabitat, along the trunk, which likely enhanced their ability to detect predators (Walsberg and King 1980).

Several small rock-dwelling passerines, such as the Rock Wren (Salpinctes obsoletus), Canyon Wren (Catherpes mexicanus), and White-throated Swift (Aeronautes saxatalis), winter at northern latitudes (Jones and Dieni 1995, Lowther et al. 2000, Ryan and Collins 2000). Information on the nocturnal roosts of the two wrens is scarce. White-throated Swifts roost in rocks or concrete structures but sometimes enter torpor during cold weather (Ryan and Collins 2003).

One of the few well-documented studies of roosting in rocks addressed the Australian Owlet-nightjar (Aegotheles cristatus) (Doucette et al. 2011). Weighing about $50 \mathrm{~g}$, the nocturnal Australian Owlet-nightjar uses rocky crevices and tree cavities for diurnal roosts. Measurements of this species' roosts confirmed that rock crevices provide excellent thermal insulation and are consistently warmer than tree hollows. Like the White-throated Swift, this species enters torpor during extreme cold.

It is, of course, unclear if the Ruby-crowned Kinglet was intending to roost in the Mount Diablo cavity on the night of 17 November 2017. The behavior Strauss observed, however, was like that of the Great Tit (Parus major), which actively explores nest boxes at sunset prior to selecting one as a nocturnal roost (Velky et al. 2010).

Scientists have long been interested in how small songbirds survive cold winter nights. Increasing our knowledge of wintering avian thermal microhabitat associations and needs is a conservation priority and deserving of further study (Walsberg 


\section{NOTES}

1985, McClure et al. 2012). Rocks and cliffs may provide critical habitat even for arboreal birds and should be protected (Rumble 1987, Matheson and Larson 1998, Lambertucci and Ruggiero 2016).

Ingrid Crickmore waited patiently in cold during this observation. Birgit Marion translated a German article. Early drafts benefited from comments by Seth Bunnell and Rusty Scalf. Geoff Geupel provided exceptional editing on an earlier version of the manuscript. Matt Baumann, Daniel D. Gibson, and Philip Unitt provided support throughout preparation of this report.

\section{LITERATURE CITED}

Antczak, M. 2010. Winter nocturnal roost selection by a solitary passerine bird, the Great Grey Shrike Lanius excubitor. Ornis Fenn. 87:99-105.

Blem, C. R., and Pagels, J. F. 1984. Mid-winter lipid reserves of the Golden-crowned Kinglet. Condor 86:491-492; doi.org/10.2307/1366839.

Buttemer, W. A. 1985. Energy relations of winter roost-site utilization by American Goldfinches (Carduelis tristis). Oecologia 68:126-132; doi.org/10.1007/ BF00379484.

Cooper, S. J. 1999. The thermal and energetic significance of cavity roosting in Mountain Chickadees and Juniper Titmice. Condor 101:863-866; doi. org/10.2307/1370077.

Dobbs, R. C., and Martin, P. R. 2000. Winter nocturnal roost sites and behavior of some desert passerines in western Texas. W. Birds 31:120-122.

Doucette, L. I., Brigham, R. M., Pavey, C. R., and Geiser, F. 2011. Roost type influences torpor use by Australian Owlet-nightjars. Naturwissenschaften 98:845-854; doi.org/10.1007/s00114-011-0835-7.

Dunning, J. B., Jr. 2008. CRC Handbook of Avian Body Masses, $2^{\text {nd }}$ ed. CRC Press, Boca Raton, FL; doi.org/10.1201/9781420064452.

Farley, G. H. 1993. Observation of a Ruby-crowned Kinglet (Regulus calendula) roosting in a Verdin (Auriparus flaviceps) nest in winter. Southwest. Nat. 38:72-73; doi.org/10.2307/3671649.

Heinrich, B. 2003. Overnighting of Golden-crowned Kinglets during winter. Wilson Bull. 115:113-114; doi.org/10.1676/03-035.

Jones, S. L., and Dieni, J. S. 1995. Canyon Wren (Catherpes mexicanus), in The Birds of North America (A. Poole and F. Gill, eds.), no. 197. Acad. Nat. Sci., Philadelphia; doi.org/10.2173/bna.197

Kendeigh, S. C. 1972. Energy control of size limits in birds. Am. Nat. 106:79; doi. org/10.1086/282753.

Lagerstrøm, M. 1979. Goldcrests (Regulus regulus) roosting in the snow. Ornis Fenn. 56:170-171.

Lambertucci, S. A., and Ruggiero, A. 2016. Cliff outcrops used as condor communal roosts are local hotspots of occupancy and intense use by other bird species. Biol. Cons. 200:8-16; doi.org/10.1016/j.biocon.2016.05.013.

Laurenzi, A. W., Anderson, B. W., and Ohmart, R. D. 1982. Wintering biology of the Ruby-crowned Kinglet in the lower Colorado River valley. Condor 84:385-398; doi.org/10.2307/1367441.

Lepthien, L. W., and Bock, C. E. 1976. Winter abundance patterns of North American kinglets. Wilson Bull. 88:483-485.

Lowther, P. E., Kroodsma, D. E., and Farley, G. H. 2000. Rock Wren (Salpinctes obsoletus), in The Birds of North America (A. Poole and F. Gill, eds.), no. 486. Birds N. Am., Inc., Philadelphia; doi.org/10.2173/bna.486

Martens, J., and Päckert, M. 2006. Family Regulidae (kinglets \& firecrest), in Handbook of the Birds of the World (J. del Hoyo, E. Andrew, and D. A. Christie, eds.), vol. 11, pp. 330-349. Lynx Edicions, Barcelona. 
Matheson, J. D., and Larson, D. W. 1998. Influence of cliffs on bird community diversity. Can. J. Zool. 76:278-287; doi.org/10.1139/z97-195.

Mayer, L., Lustick, S., and Battersby, B. 1982. The importance of cavity roosting and hypothermia to the energy balance of the winter acclimatized Carolina Chickadee. Int. J. Biometeorol. 26:231-238; doi.org/10.1007/BF02184939.

McClure, J. W., Rolek, E. W., and Hill, G. E. 2012. Predicting occupancy of wintering migratory birds: Is microhabitat information necessary? Condor 114:482-490; doi.org/10.1525/cond.2012.110139.

McKechnie, A. E., and Swanson, D. L. 2010. Sources and significance of variation in basal, summit and maximal metabolic rates in birds. Current Zool. 56:741-758; doi.org/10.1093/czoolo/56.6.741.

Reinertsen, R. E., Haftorn, S., and Thaler, E. 1988. Is hypothermia necessary for the winter survival of the Goldcrest, Regulus regulus? J. Ornithol. 129:433-437; doi. org/10.1007/BF01644486.

Rumble, M. A. 1987. Avian use of scoria rock outcrops. Great Basin Nat. 47: 625-630.

Ryan, T. P., and Collins, C. T. 2000. White-throated Swift (Aeronautes saxatalis), in The Birds of North America (A. Poole and F. Gill, eds.), no. 526. Birds N. Am., Inc., Philadelphia; doi.org/10.2173/bna.526.

Ryan, T. P., and Collins, C. T. 2003. Activity patterns of White-throated Swifts in California. W. Birds 34:186-198.

Schleucher, E., and Withers, P. C. 2001. Re-evaluation of the allometry of wet thermal conductance for birds. Comp. Biochem. Physiol. A 129:821-827; doi. org/10.1016/S1095-6433(01)00356-7.

Skutch, A. F. 1989. Birds Asleep. Univ. of Texas Press, Austin.

Swanson, D. L. 2007. Cold hardiness and summit metabolism in North American kinglets during fall migration. Acta Zool. Sinica 53:600-606.

Swanson, D. L., and Garland, T., Jr. 2009. The evolution of high summit metabolism and cold tolerance in birds and its impact on present-day distributions. Evolution 63:184-194; 10.1111/j.1558-5646.2008.00522.x.

Swanson, D. L., Ingold, J. L., and Wallace, G. E. 2008. Ruby-crowned Kinglet (Regulus calendula), in The Birds of North America (A. Poole, ed.), no. 119, version 2.0. Cornell Lab. Ornithol., Ithaca, NY; doi.org/10.2173/bna.119.

Velky, M., Kanuch, P., and Kristin, A. 2010. Selection of winter roosts in the Great Tit Parus major: Influence of microclimate. J. Ornithol. 151:147-153; 10.1007/ s10336-009-0436-9.

Walsberg, G. E. 1985. Physiological consequences of microhabitat selection, in Habitat Selection in Birds (M. L. Cody, ed.), pp. 389-413. Academic Press, New York.

Walsberg, G. E. 1986. Thermal consequences of roost-site selection: The relative importance of three models of heat conservation. Auk 103:1-7; doi.org/10.1093/ auk/103.1.1.

Walsberg, G. E., and King, J. R. 1980. The thermoregulatory significance of winter roost-site selected by robins in eastern Washington. Wilson Bull. 92:33-39.

Weathers, W. W., and van Riper, C., III. 1982. Temperature regulation in two endangered Hawaiian honeycreepers: The Palila (Psittirostra bailleui) and the Laysan Finch (Psittirostra cantans). Auk 99:667-674.

Wetmore, A. 1936. The number of contour feathers in passeriform and related birds. Auk 53:159-169; doi.org/10.2307/4077274. 